\title{
心理学における空間概念
}

\author{
印 東 太 郎
}

(殿応義㠇大学心理学研究室)

\section{Space concepts in psychology}

\section{TAROW INDOW}

デカルトは mind と matter を区別するに当り，一死

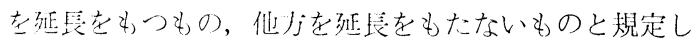
たといわれっ。至の意味では，すなわち，Daseinとして

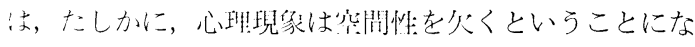

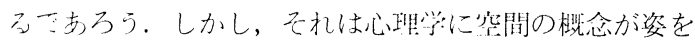

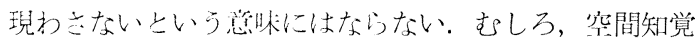

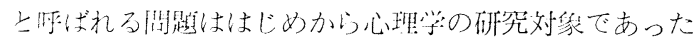

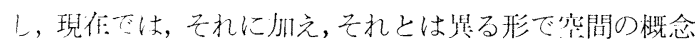
は心理学の研究の中に焦埸してくるのである。そこで，

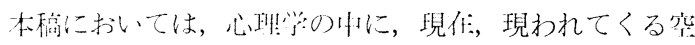

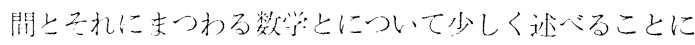
したい.

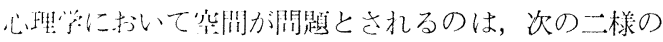

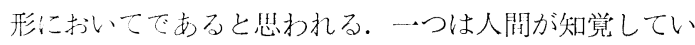
る究間その斗の，ないし，知觉している事象の空間的関 倸一，一船に筞間知觉 (space perception) と称されるも

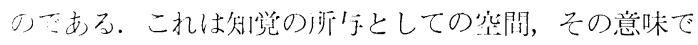
は，いわば具体的な钞䦌ということができる。もう一つ は，心理学的事像を衣現するための手段として想定され る抽缘的な等間と呼ぶとができよう。いずれの場合 子，空間概念の導入の初期に扔いてはともかく，やがて はそれを数学的に表現することが試みられるようになっ た。本稿においてはそういう突間概念とそこにおける数 学とに重点をおき，突間に関するそれ以外の問題には立 大らない，事実，空間が登場してくれば，それが登場し ない場合にくらべ, 数学檤用され易くなり，いわば数 学適用の場ができるといえよう.心理学の研究において, 統計学の必要なことは比較的知られているのに反し,リ 一マン幾何兴行冽が用いられていることは一般に知ら れていないと想うのでこの機会にいささかそのPRを 試みたのである。

\section{1. 空間知覚の問題}

歴史的にはこの方がはるかに古くから扱われていたの で，上に述べた分類の第一の方，空間知覚をまず取上げ る. 空間知覚という蓄は, Carr.女指摘しているように [4]，空間そのものの知覚をさすような響きがあって都 合が鍶かが，むしろ，知覚の中に打ける空間的性質を意 味するむのというべきであろう。人間に知覚されている ものは質，強度などの属性（attribute）—Boring [1] の表現でいえば次元（dimension）——をむが，特に “見えているもの，”“聞こえているもの”, および，“皮 屋で感じているもの, ”すなわち, 少くとも視覚, 聴覚, 触覚においては, さらに, 抎がり, 空間の属性, 次元を もち，その“もの”は形，大きさ，空間内に拈ける位置 を多って知覚されている. したがって，空間知覚として 取上げられてきた問題としては，たとえば，物体の形の 認知と，錯視などその歪み，三次元的物体における奥行 きの知覚の成立, 光点, 竞, 触点の定位などがあげられ る.このように，一船に等临知覚という総称の下に研究 されてきた事象はいずれ子知覚されたもの自身の空間的 属性であって，空間そのものではないかもしれない. しかし，知覚されたものがその中で形，大さをもち，そ の中で位置を占め, その中で運動して知賞されるために は，そこに連続体としての空間—それ自身が知覚され ないにしても一一の存在を前提としていると思われ，こ の空間は, 当然, 物理的空間ではなく，心理的空間，現 象空間 (phenomenal space) であろう。この種の空間と その数学的表現が本節の主題となるのである.

空間知覚は, 少くとも人間に执いては, 何といっても 視覚によって代表されるであろう。そして, 視空間知覚 の研究は，その初期にあっては，はなはだ哲学的色彩が 濃かったといわなければならない[2，p.221]. 空間を 直観の先験的形式としたカントの影響をうけ，視空間を 先天的とみるか，後天的・経験的とみるかについて，い 
わゆる nativism (Descartes, Kant, Hering, J. Müller, Stumpf など) と empiricism (Locke, Lotze, Wundt, Helmholtzなど）の論争が行わ机たようである.しかし， この場合, 視空間とは何を意味するものであるか, 先天 的, 後天的を区別する操作的定義を何に求めるべきかに ついては余り統一されていないようで, 今日の実験心理 学者の目から見ると，何を論じていたのか，そのポイン 卜のつかみ難いきらいがある。現在，こういう形で問題 を設定しょうとする心理学者はまずいないであろう。上 述の問題に最煞関連の樑い今日の具体的研究テーマをあ げるとすれば，それは盲人の開眼手術後における視覚経 験の臨休例の蒐集であるが [38]，しかし，この種の問 題は, 現在のところ, 数学的表現の対象にはなり難いの で, 本稿に执いては取上げない。

視空間知党に関し，かって取上げられた問題の中で最 ๖具体的な子のの一つとして網莫像転倒の問題 (inversion of retinal image) あるいは正立視 (upright vision) と呼ばれる問題をあげることができよう. 根球内の受光 泊i一網膜——には，眼の光学的構造と幾何光学の法則 にしたがい, 外界の物体の転倒した像が結ぶ.しかし，人 間にはその物体は正立した形で知営される，これはおか しいというのがこの問題で, 上述の nativism-empiricism とわ関連し，かって大いに問題とされたらしい[4, chap. III]. この問題のおは, 一般的な nativism-empiricism と は買り, 少くとも取上げている問題内容の焦点はよく理 解できるであろう。ただし，上述のような閴題の設定そ のものは似iirij非問題 (pseudoproblem) で，そのことが 理解されるようになったのはヘルムホルッの Handbuch der Physiologischen Optik, III, 1866 の頃加であった といわれる [2，p．224]. すなわち，上述の事実が矛盾 に思われるとすれば，それは二つの全く別種の空間—— 物理的空間と視空間——に関する座標を混同しているか らに他ならない，網膜に抢いて，外界の対象 A-B の転 倒した像 $\mathrm{A}^{\prime}-\mathrm{B}^{\prime}$ が結ばれるというのは,物理的空間の座 標系についてのことであるが，一方，その人にとってA に対応する部分の知覚 $\mathrm{a}$ が $\mathrm{B}$ に対応する部分の知覚 $\mathrm{b}$ より上に，網膜の上では $\mathrm{B}^{\prime}-\mathrm{A}^{\prime}$ になっているにもかか わらず，a-b の形で正立した位置に見えるという時の座 標系は視空間に関するもので，物理的空間の上下あるい は方:右と，視空間の上下あるいは左有との間には㨁接の 関係はないのである。この場合, 問題とされるべきもの は，物理的空間内部の空間的秋捻に対応する視空間内部 の空間的秋序の成立機劣に関する一般的問題であって, 物理的空間の座標系でいって下にある部分 $\mathrm{A}^{\prime}$ の知覚
像 a が視空間で上位に見えていることだけに特別の問 題にある訳ではない，そのかわり，かりに人間の視覚光 学系の中にペンタプリズムが内蔵されていて，対象の正 立像が網膜に結ぶものとし，綃膜で上位にあるものが視 空間で上位に知覚されるような機構になっていたとして も，それで問題の解消することにはならないのである.

上述の上うな似而非問題の㧊こるのは，二つの空間， 物理的空間と視空間,より一般的には現貌空間，とを峻別 して考えるのがかなり困奞なことを示している，両者を 区別して扔かないと，この他には，いろいろと似而非問 題が生じるのである [8]. これら二つの空間が異るから こそ, 後者すなわち視空間, 恥空間, 触空間などの概念 を正しく措定すること，および，それを数学的に表現す ることが心理学の問題になるというべきであろう.

視空間知覚の中で, 最初に数学的表現の与えられた事 象は，多分， horopter と呼ばれるものであろう。これは 適当な訓語がないようなので，以下，ホロプターと書く が，その測定法，したがって，その操作的定義にはかな りいろいろな形がある [31，p.18]，その中で実際上し ばしば用いられてきた定義は“闲腿で 1 点を㠜視してい る観察者にとり，凝視点を通る前額平行 (fronto-parallel）面に知党される刺战点をつなげた轨跡”であろう. 三次元的に取扱うとかなり複㮅な形をとるが，㠜視点が 两眼と同じ高さにある場命に限定すると，此較帕简単な 州線になる，その場命，前額平行というのは観祭者にと って，手前に凸にも叫にも見えず，横に一甶線に知覚さ れるという意味である.人間が平らな壁に正対して泣て ば，その壁の少くとも中央の部分は前额平行に知覚され るであろう。しかし，普通の室内のように壁以外のいろ いろの物体が視野の中にあったりしては理論構成が難し くなり，また，壁以外に何もないとしても，壁のような 連続面を用いると事情が変ってしまう打それがあり，木 ロプターの測定を行う場合には, 通常, 無地の闻の前に 細い棒を並らべ，それらが前額平行に見えるまで観察者 に棒の位置を調整させる方法をとる。 ホロプターという 概念の導入されたのは非常に古く，人間の腿は二つある のに一般に物体は一つしか見えないが，注意すれば二重 に見えるものも少くないというような観察と関連して, 決して二重像には見えない点の軌跡というような意味で あったらしい(F. Aguilonius: Opticorum librisex, 1613)

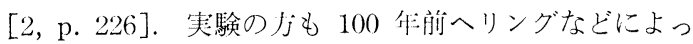
てすでに行わ机ている.

凝視点を两胀の高さにした場合は特に longi tudinal horopter と呼ばれるが，教科書などではしばしばこれを 


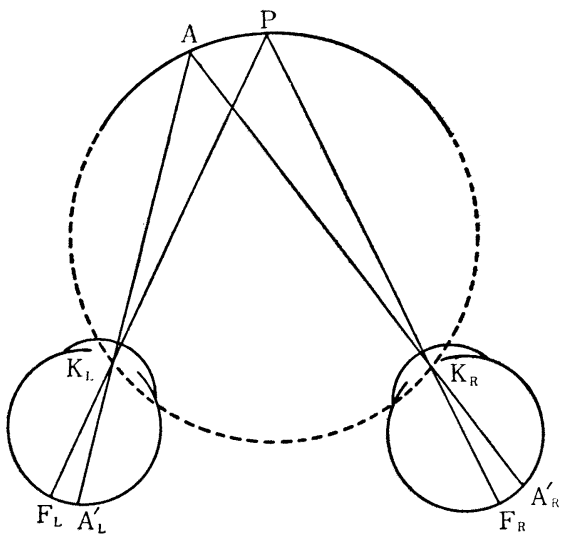

Fig. 1. Vieth-Müller circle $K_{L}, K_{R}$ 打よび $F_{L}, F_{R}$ はそれぞれ左，右眼の

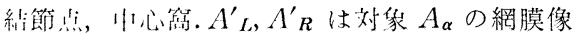

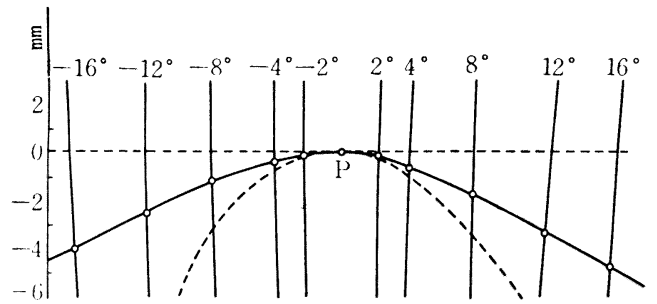

践㒕 $20 \mathrm{~cm}$

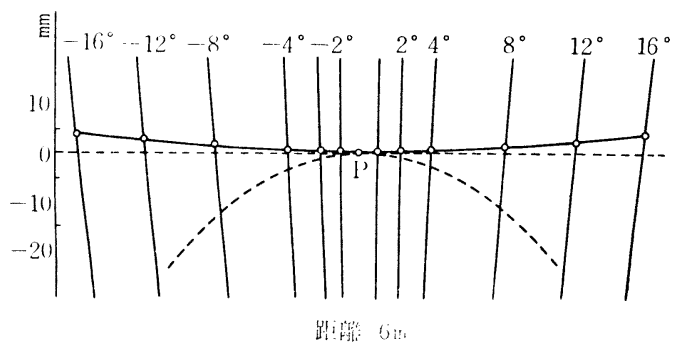

Fig. 2 Longitudinal horopters Pは凝視点，点線は Vieth-Müller circle

雨眼の結節点 $\mathrm{K}$ と凝視点 $\mathrm{P}$ を通る阿としている（Fig. 1).この阿は正しくはVieth-Müller circle と呼ばるべ きもので，実験の結果によると， longitudinal horopter は必ずし斗この形にはならない.ホロプターの方は凝視 点の位醞によりその形が変り，凝視点が観察者の近くに ある間は前方に凸，凝視点がある限度以上遠く離れると 手前に凸になるのである（Fig. 2).こういう形をもつホ ロプターに関する数学的考祭はすでにヘルムホルツによ っても試みられたようであるが，此較的最近になってか らは Ogleによって組織的な研究が行われた [27〜31].
彼は㠜視点の距離により上述のようにその形を変える ホロプターを阿錐䌷線の family で表現することを考え， かなりの成功を打さめた，事実，Fig. 2 に記入されて いる実線の曲線は彼の式を fit したもので, 実测結果に よく適合している.もっとも，ホロプターが円錐曲線の 形をとらなければならないという論理的必然性は認めら れないので,ただ,そ扎を四錐且線と考えてある一つのパ ラメーターの碑を変化させ扎ば実験結果によく一致する 曲線群が得られるというのに過ぎないのであるが，この モデルの魅力の一つは，荫腿のレンズの抎大率が等しく ない場合に見られるホロプターの特色的な歪みが同じ式 から定量的に導出できるという点であろう。まだ-つの まとまった理論というよりは，一つの記述モデルという べきものと思われるが，ホロプターのような視空間知賞 に㧍いて長年用いられてきたもの斥，心理学の進䒚とと 夗に，その取报いは数学的な形をとるようになってき た．実際，空間的ということは，それに数学的な形を与 え易いということはほかならない。

しかし，上述のホロプターに関するモデルは，視空間 知覚の一事象の問題で，これは未だ視空間そのものの数 学的表現ではない.したがって，こういう個別事象の数 学的表現の進められてゆく反面, ホロプタ一の事実をは ほめ，視空間知覚という一般的名称の下に包括される諸 現象がその中に打いて生起する視空間その女のを考え， その性格を数学的に表現することにより，一挙に諸現象 に説明を与えようというスケールの大きい試みの現われ るのは当然であろう。 Luneburg の提出した雨腿視空 間に関するモデルはその線をゆくものと思われる [21〜 $23]$.

さきに物理的空間と視空間とを峻別する必要のあるこ とを述へた。前者は光点など視覚対象がその中に位噌を とる空間，後者はその中に知覚されたものが位倠点め る空間である.ある視覚対象 $Q$ の物理的空間における位 置を表わすには，観察者の両眼 $L, R$ との関係圭明らか にするため, Fig. 3 のような双極夾標系を用いるのが便 利であろう。また，われわれの目的にとっては，物理的 空間はユークリッド空間と考えてもさしつかえないもの と思われる. 点 $Q$ の位置は三つのパラメーター $\gamma, \phi, \theta$ で与えられ， $\theta$ は仰角， $\phi ， \gamma$ はこの座標系に扩りる緯 度，視差である。一力，Qの知覚されたものを $P$ とすれ ば,それは視空間の中に位置を占めるが，もし視空間内の 空間的秩序が物理的空間内の空間的秩序によってそのま ま規定されるものとすれば，Fig. 3 の $Q$ はそのまま $P$ を表わすことになり，Fig. 3 は視空間の map となるで 


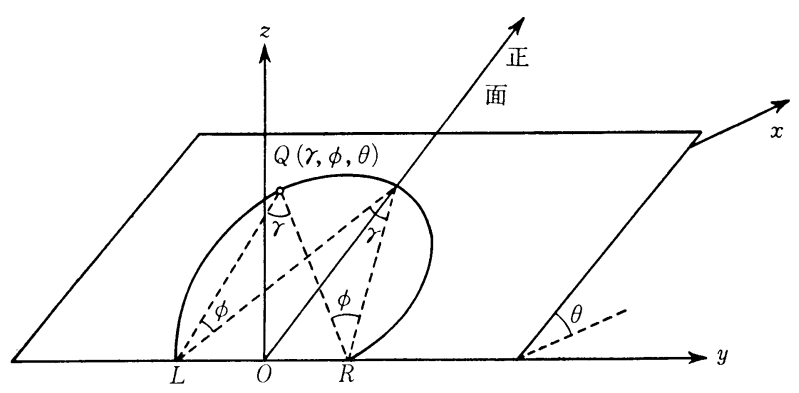

Fig. 3

あろう．ところが，多くの観察事実は Fig. 3 がそのま ま視空間の map にはならないことを示しているので, たとえば，最も日常的な観察事実についていえば，物理 的には無限遠点にある星や月 $(\gamma=0)$ は視覚的には有限 の半径をもつ天球の中に位置をとって見える.ルナバア グは綿密な考察から，少くとも暗䦣の中に幾つかの小灮 点だけが与えられているような単純化された条件の下で は，両腿視空間は一つの定朋摔計量空間（homogeneous metric space）と見做し得ることを論証し，それを表わ す Euclidean map として Fig. 4 のような座標系を用 いたここの場众，杪を一つにしたのは，われわれの就

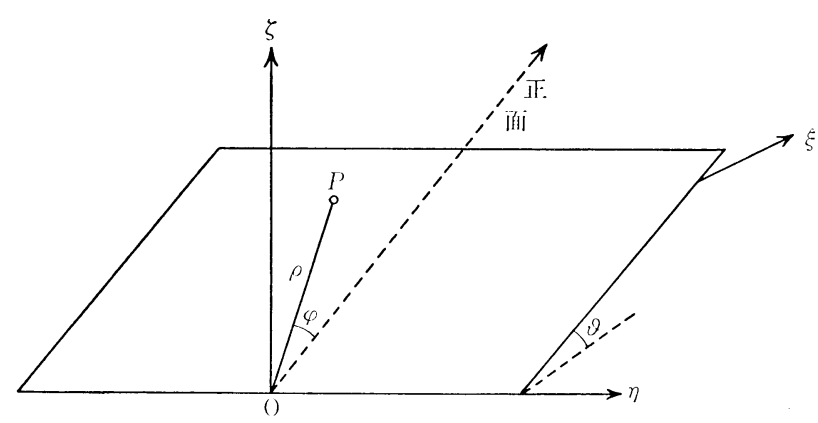

Fig. 4

的経験には両服で対象を見ているという客観的事実は全 く反映されていないからである，知覚された $P$ 点の位羁

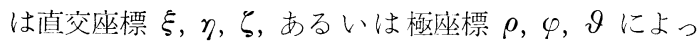
て与えられ，彼は物理的空間と視空間との対芯を次のよ うに仮定した。

$$
\left.\begin{array}{l}
\vartheta=\theta \\
\varphi=\phi \\
\rho=2 e^{-\sigma \gamma}
\end{array}\right\}
$$

上の二式は, 経験的事実として, 上下, 左右の方向に 関し視覚対象 $Q$ の位置はほぼそのまま視知覚 $P$ に反胦 されることを示し，第三の式は物理的に無限遠点 $(\gamma=0)$
にある $Q$ が map の上では $\rho=2$ という限界を とるよう定䉝しているのである。なお， $\sigma$ は奥行 知覚に関するパラメーターで，人によってその值 は異る。もし，視空間がュークリッド空間であれ ば，Fig. 4 上の空間的秩㐨が視空間の空間的秩 リの南接的表現になっているはずであるが，多く の観察事実はそれに対して不定的て，ルナバアグ

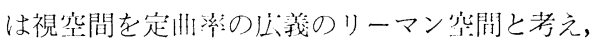
その線素を

$$
d s=\left(\begin{array}{c}
d \xi^{2}+d \eta^{2}+d \zeta^{2} \\
1+\left(\frac{K}{4} \rho^{2}\right)^{2}
\end{array}\right)^{\frac{1}{2}}
$$

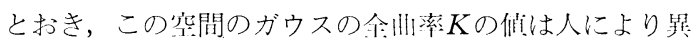
なるが，一般に $K<0$ と考えられることを示した。すな

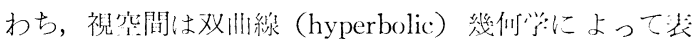
現されることにほかならない.

このような視产閒そのむのに関するモデルから，視穷

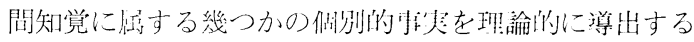
ことができる。ささきに述へたホロプターに関する事䒠

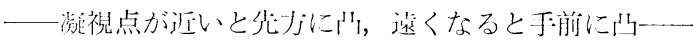

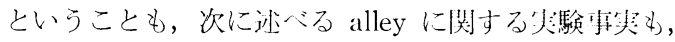
定州的には，このモデルから艼けむれ，も一つ， Amesによって示された distorted room と称

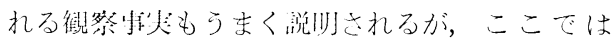
alley 桀験についてのみ嘚単に此ぐることにする.

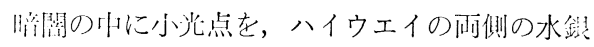

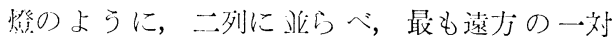
$\left(Q_{O R}, Q_{O L}\right)$ は国定して，他の光点はそれを起点 として，钼祭者にとり少斿から手前に们い平行な 二列に兒えるよう位䍇を調断した絬果を parallel alley といい, 一方, 光方から手前に向う光点の 各対 $\left(Q_{i R}, Q_{i L}\right)$ が起点の一対 $\left(Q_{o R}, Q_{o L}\right)$ と 同じ間隔に離れて見えるようその位筧を調整した結果を distance alley という. 以下, 能者を平行アレイ, 後者を 等距離アレイと呼ぶが，阔者は一致せず，一般に等距離 アレイは平行アレイの外側に出る事些は 1902 の Hillebrand, 1913 の Blumenfeld の实験以米知られていた。 すでに半壮紀を経過し，現作なら当然豆電球を用いると ころであるが，当時はガスの炒老使用したりして実験が 行われた時代のことのである。洢単のため光点はすべて

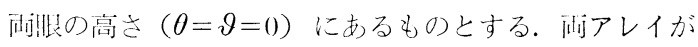
一致しないという查呂は视突間か非ユークリッド空間で

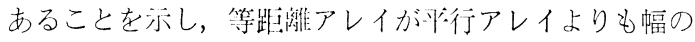


㕕くなることは，ルナバアグの体系からいえば，(2) 式

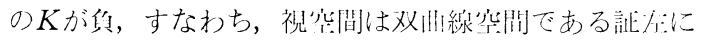
当る. 事实, 平行アレイ, 等距谁アレイの条件の下で, $K<0$ として（2）式の線素かり変分法により测地線 (geodesic) を求め，（1）式によりそれを物理的無間に引 き移すとたしかに等趾测アレイは惟行アレイの外侧に なり，それは $K<0$ の埸们限るのである。

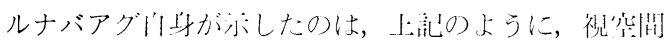

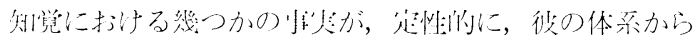

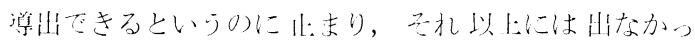

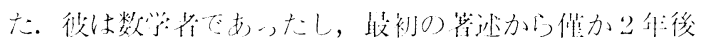

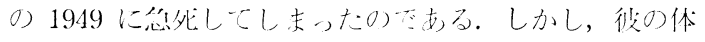

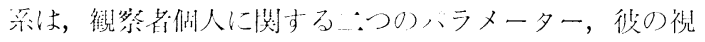

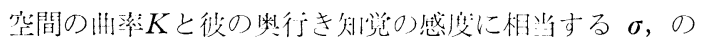

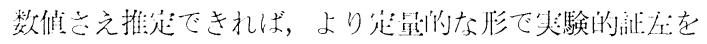
求め得るはずで，現倠そういう所究は连際に行われるよ うになっている $[6,7,13,14,16,39,40]$. もとより,こ の尖験的検䟚は相当に嚾しい，モデルそのものが事卓の

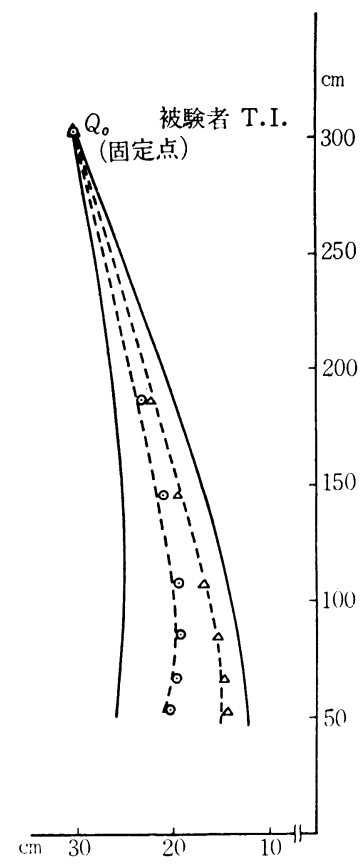

……の結果から推定し たもの

$K=-0.35 \sigma=13.0$ 他の扰䮖から推范し たもの

$K=-0.77 \quad \sigma=-12.6$

Fig. 5 非行( ( ) 拉上び等 距離アレイ(左側のみ) oversimplification である ことは明らかであるが， そのほかにもいろいろ困 踓な点が少くないからた ある.ここにはわれわれ のところで得られた最も 代表的な実験結果を一つ だけ Fig. 5 に示してお こう。闵は筆者自身が観 察者になった場合の，

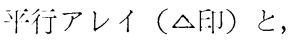
等距酷アレイ (○印) の 笑験絬果を，アレイのを: 側のみを六しており，ま た，点線の鳈はこれら の尖験結果から推定した $K$ と $\sigma$ の値を用いて計 邻した理諭アレイ曲線， ‘緃の出線はこの'尖験と は全然別䇢の方法に推定 した $K$ と $\sigma$ の值を用い て計简した理論アレイ帏 總でする。この美験絬界 からパラメーターの值を 推定军礼淁，点線の示寸 ように，結果によく適合
する平行，等距離アレイの曲線をひくことができるが， 別の方法で推定して扔いた $K$ と $\sigma$ の佔をもってくる と，系統的なはつれが現われる場合が多い。この例はち ょうどこの偏筒の代表的な程度を示しており，もっと よく適合するケイスも少くないが，何時で充ううまく はゆかないようである。しかし，篗者の研究室に打ける 結果では， $-1 \leq K \leq 0$ ということは確加しく，8名の 钼祭者についての計 52 例に㧊いてそれ以外の梿となっ たのは2例に遇ぎない $[13,14]$.

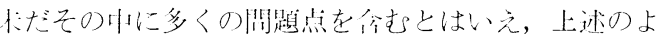
うな佂劣の路線は，科学としての，特に数理科学として

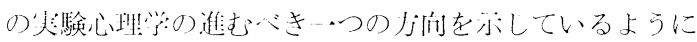

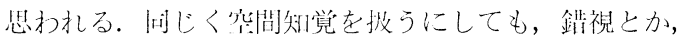

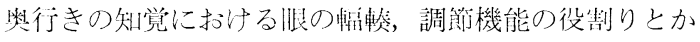
の湖别的問題をそれ自身として取上げることも，女ち万 ん，必要であり，30 年前 Carr の書物 [4] の著わされ た項には，こういうスタイルの研究しかなかった訳であ るが，てれ以外に大きな枠として視空間というものを描 定し，それに数学的表現を与えることにより，一連の個 別的現象を統一的に導出することを狙うスタイルの研究 も試みられてもよいであろう。そのかわり，徽分幾何 学, 変分法など, 従来の観念からいえば打よそ心理学者 にとって縁のなさそうな道具立てが必要とされる，ルナ バアグのモデルを例として，心理学に非ユークリッド空 間の概念の登場するゆえんを述べたのである.

空間知覚に拈ける空間としては，上に扱った視空間の ほかに，聴覚，触覚に扮ける空間があり，ここでも二つ の耳に与えられる音刺㦸が一つの德空間をつくる問題 [5]，聴鸴と触覚との間に見られる空間的属性に関して の警くべき一致 [37] など，多くの問題があるが，それ らに言及することは紙数の都合で割愛したい，それにし ても，音響に拈けるステレオ再生は非常な勢で普及し， ステレオテレビショョンが研究されつつある今日，空間知 覚に抢ける空間の問題は，技術的にも興味ある研究テー マというべきであろう。

\section{2. 心理学的事象表現するための空間}

次に，序に述心た第二の意味に扔ける空間，すなわ ち，心理学的事象を表現するための空間を取上げる.こ れは, 統計学でいえば標本空間 (sample space) とか径数 空間（parameter space）など，物理学でいえば Gibbs の相空間 (phase space), 情報理論でいえば信号空間 (signal space)というような子のに相当する.

筆者の知る限り，心理学にこの種の空間を最初に導入 したのは Lewin であ万う [18〜20]. 彼はある瞬間にあ 
る個人 $P$ の行動に影響を及ぼすすべてのものを含めた抽 象空間を考え，これを生活空間 (life space) と呼んだ. 通常，個人もこの空間に含まれ，その他，彼の行動の目 標とか，目標に到達するためにふまなければならないス テップとか，それを妨慧する事抜などがそれぞれこの突 間の一つの領域になり，Pの行動はこの空間内の移動と して表現される.レヴィンは，この空間を表わすのに最 初は topology を用いようとし, 後には方向や距離を導 大するために彼が hodology と名ゔけたもを用いた。 レヴィンのこの試みは, 当時, 漠然と心理学に数学を導 大することを眴望していた一部の人々をかなり喜ばせた ように思われる. 誰にも理解でき，しかも数学の言葉を 用いて話すことができたからである.しかし，筆者の個 人的意見としては，topology あるいは hodology により 生活空間を表わそうという意図そのものはレヴィンのの 死とともに余り実も結ばずに終り，彼の業績の中で後に のこったのは, むしろ, Untersuchungen zur Handlungsund Affekt-Psyhologie のタイトルの下に Psychologische Forschung 誌上に揭載された約 20 篇の実験的研究の力 ではないかと思われる. 経験科学としての心理学にとっ て, topology ではそこから生産的な帰結を導く可能性は 少いといわざるを得ない.人間の行動を表わすのに生活 空間のような一種の 状態空間の概念を採用するとすれ ば，行動をその中において遷移確率を最大にする path と考える戸田氏の体系 [36] の方が，理論的枠組として はより具体的であろう。これも，しかし，そこに含まれ ている直観希望值といった量が実際に数值として具体化 されない限り，そこから具体的な行動の予测を導くこと は困難と思われる.

人間の行動一般を表わす相空間のようなものを想定し ようとすれば, どうしても抽象的な性格を带びざるを得 ない.しかし, もっと限定された, 個別的な心理学的事 象を表現するのに空間概念を用いるのは，有効でもあ り，奖励されるべきことであろう。この種の空間の中 で, 古くから考えられ, その研究も最も進んでいると思 わ扎るのは，いわゆる色空間 (color space) である.

色空間というのは，空間的に㹡がった色の知覚ではな く, 人間の知覚し得るすべての色を, 適当な方法にした がい，空間的に配䈕した体系の意味で，通常は 3 次元の 立体が考えられる. 配置の方式にはいろいろあり, 純粋 に测色学 (colorimetry) における便宜上からきめられた $\mathrm{XYZ}$ 表色系のようなものもあるが，之の場合でも人間 が 2 色の間に知覚する相違の大きさ一色差一一どを その空間における距離として表現しょうという心理学的
原理を加味すると, ULCS 﨎色系 (uniform lightness chromaticness scale system), ょり一般仙には MCS (metric color space) の問題となり [33]，XYZ 表色系 そのものは国際的に確泣しているのに反し，この力はま だ決定盤はない，色彩は人間の知覚現象であるから，知 覚された色彩相互間の秋污が允分その中に反映するよう 構成された色無間は，まさしく，本節でいう空間の一例 であるＸYZ 表色系から田発して ULCS 系を求める 場合に用いられる数学は微分幾何学: [24,34など], 身 影幾何学 [17など]などがうになっている。一力， 、 ンセル (Munsell) 繂色系と呼ばれる色空間の力は, XYZ 表色系とは暴り，最初加人間の湖に見える色の関係を 表現することを基本方式として構成されで抢り，この三 次元の色空間が，全体として，ユークリッド性をむつと 考えてよいか令かというような問題を検討しようとする なら, 多次元的尺度構成 (multidimensional scaling) と いう手法を適用するのも一つの)法をむる $[35,8,10$, 11$,$] .$

この多次元的尺度構成と呼ばれる手法は，一般的に述 べれば，次のような内谷をもっている [35]. $n$ 個の对象 $O_{i}(i=1,2, \cdots \cdots, n)$ に拈いて, 組令せ $\left(O_{i}, O_{j}\right)$ につき, その間に何らかの意味で距漼として表現できるような心 理学的性質 $\Delta_{i j}$ があり, $O_{i}$ をその相互間の距離が $\Delta_{i j}$ に 比例する点の价置として表現したい場合，（i）その死琵 は実ユークリッド空間 $\Omega_{m}$ の中に想定することが可能 であるか否か，(ii）可能であ机ば，その次元 $m$ を決定 し, (iii) 同時に, その们罚の形を奏際に求める, という ものである. 実験によって $\Delta_{i j}$ に比例する数量 $d_{i j}$ が 求められているものとし，それを相互の距離とする点の 布置を考える (Fig. 6). これは何次元かの然間に何らか の形をとっているであろうが，その何処かに $n$ 個の点の 重心 $O$ が存在するであろう。そこた，重心 $O$ から各点 $i$, $j$ などにいたるヴェクトルを考え，その内積在 $b_{i j}$ と書 けばこれは $d_{i j}$ などから次の式によって計算空れる。

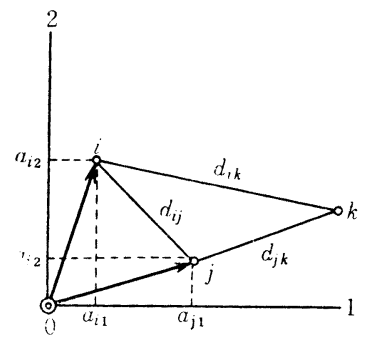

Fig. 6 


$$
b_{i j}=\frac{1}{2}\left\{\frac{1}{n} \sum_{i} d_{i j}{ }^{2}+\frac{1}{n} \sum_{i} d_{i j}{ }^{2}-d_{i j}{ }^{2}-\frac{1}{n^{2}} \sum_{i} \sum_{j} d_{i j}{ }^{2}\right\}
$$

ところが，重心 $O$ を原点とする仕意の $m$ 次元直父坐標系 を考光，各点 $i$ のそれに刘する座標を $a_{i s}(s=1,2, \cdots \cdots$, m) とすれば,

$$
b_{i j}=\sum_{s=1}^{m} a_{i s} a_{j s}
$$

と書ける。したがって， $b_{i j}$ 在要素とする $n \times n$ の行列 を $B, a_{i s}$ 老贤素とする $n \times m$ の行列在 $A$ とす机ば，

$$
B=A A^{\prime}
$$

となる、たたし， $A^{\prime}$ は $A$ の伝置行列とする。すなわ

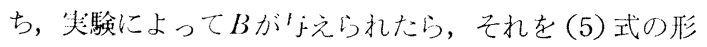
で $A$ という行列に分解できれば, $A$ 列の数が $m$, その 要素 $a_{i s}$ によって求める点の们㽡が定まるのである. し かし， $B$ は何時でも（5）式の形に分解できるとは限ら ない. $B$ は対称行列であるから

$$
U^{\prime} B U=\left(\begin{array}{ccccc}
\lambda_{1} & 0 & \cdots & \cdots & 0 \\
0 & \lambda_{2} & & 0 \\
\vdots & \vdots & & \vdots \\
\vdots & \vdots & & \vdots \\
0 & 0 & \cdots & \cdots & \lambda_{n}
\end{array}\right)
$$

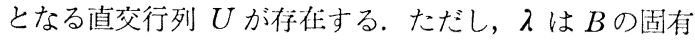
值である.（6）式から

$$
B=U\left(\begin{array}{ccccc}
\lambda_{1} & 0 & \cdots & \cdots & 0 \\
0 & \lambda_{2} & \cdots & \cdots & 0 \\
\vdots & \vdots & \ddots & \vdots \\
\vdots & \vdots & & \vdots & \vdots \\
0 & 0 & \cdots & \cdots & \lambda_{n}
\end{array}\right) U^{\prime}
$$

であるから，

$$
A=U\left(\begin{array}{ccccc}
\sqrt{\lambda_{1}} & 0 & \cdots & \cdots & 0 \\
0 & \sqrt{\lambda_{2}} & \cdots & \cdots \\
\vdots & \vdots & \ddots & \vdots \\
\vdots & \vdots & & \vdots \\
0 & 0 & \cdots & \sqrt{\lambda_{n}}
\end{array}\right)
$$

したがって誤差を度外視して述べれば，(i） $\lambda_{s} \geq 0$ で なければ，点の布置は奉ユークリッド空間 $\Omega_{m}$ に収めら れないし，(ii） $B$ の階数，すなわち， $\lambda_{s}>0$ の 入の数 $m$ がその空間の次元を示すのである.（iii）また，(5) 式の形で最小自乗法的に所与の $B$ を再現する $A$ は $\lambda_{s}$ に対応する $B$ の固有ヴェクトルを列とする行列である ことは容易に証明される，ただし，幽有ヴェクトルの成 分の単位は,

$$
\sum_{i} a_{i s}{ }^{2}=\lambda_{s}
$$

としなければならない。

マンセル色空間は, 上述の多次元的尺度構成の見地か らいえば, 少くとも第 1 次近似としては，3 次元のユー
クリッド空間でよく表現できるように思われる $[10,11]$. ところが, 距離として表現されるような心理学的性質 $\Delta_{i j}$ は，マンセル色空間の検討の場合には任意の二色 $i, j$ 間の色差であるが, 他のどのようなものであって も，多次元的尺度構成のモデルに適うものであれば，さ しつかえない訳で，たとえば，人と人との友穸（friendship）の分析にこの才j法を適肋することも考えら机る [26]. 二人の人間 $i$, と $j$ の間の友父とは，操作的にい えば，仕事以外の余脚に $i$ と $j$ のさ合う度合と定義 することができ，その度全在適当に $d_{i j}$ として数做化で きれば，友忞橆間ともいうへきもの在適当な次元のユ一 クリッド空間として衣現できるか售かが各観的に明らか になるであろう，その他，ある社公的態度 $i$ をとる人は 同時に他のある社会的態度 $j$ をとる傾向があるとか，な いとかいう各社会的態度間の親近性を $d_{i j}$ として表わせ ば，態度空間とも称すべきものを構成する可能性もひら けてくる [25]. 実際には，しかし，色差の上うなもので さえ，これを $d_{i j}$ として数値化するには相当の困難があ り，ましてや，友交の程度や態度の親近性となると， $d_{i j}$ を求めるところにまず解決しなければならない問題 があり, それは多次元的尺度構成が広く心理学のいろい ろな事象に適用されるための一つの前提であろう。もう 一つの方針は， $d_{i j}$ と $\Delta_{i j}$ 間によりゆるい条件の成立し か前提としない解析法の発展であり [32]，より寛大な空 間にお污る布置の構成を可能にすることであろう.

多次元的尺度構成に限らず，心理学においては Thurstone の最初の体系的書物 The vectors of mind (1935 の出版から数えても約 20 年の歴史をもつ因子分析法 （factor analysis）も，そ机を有効に適用するというのは， そこに一つの $m$ 次元空間を, 本節でいっている意味での 空間を，構成することにほかならない [15]．因子分析 法は主として知能や性格の解析に適用されてきた。 ただ し, 多次元的尺度構成や因子分析に打いて想定される筀 間は, 点相互の関係, 点の布置が第一義的に規定され，そ の空間の座標系は第二義的にしかきまらない，その点， 自由度 $N$ の Gibbsian ensemble に対し， $2 N$ 次元の值 交坐標系が先に与えられる相空間などとは，いずれも状 態を表わしているにせよ，かなり越を異にするのであ る. 篗者は心理学においても, 今後, 後の意味での状態 空間か導入されてよいと思っている.

筆者は，心理学の，あるいは，心理測定学の一つ”の 萝は，次のようなものであろうと常に考えている，すな わち，座標系からきめるにせよ，点の布置から構成する にせよ，人間の personalityに関するすべての可能な状 
態をその中の点として含む一つの状態空間, personality space とも称すべきものをがっちりと構成し，この空間 を適格に表現すべき数学を明らかにし，個々の人間をこ の frame of reference の中に位置つける操作をきめる という研究方針である，色彩の体系に抋いてさえ，MCS はまだ決定盤はないのであるから，客観的に通用する metric personalityspace の構成の容易でないのは明らか であるが，少くともそういら一つの目標に向って研究の 蓄積を收斂させてゆくことは必要であろう。そのために は, しかし,空間を报う数学を一つの支柱としてゆかなけ ればならない，上い道具を選ぶということは成功の第一 歩であろう。理学以外の方々にも，上述の上うな問題 の所在を知って頂いて，御援助を柳ぎたいものである.

本節に述べた意味の空間としては，上述のようなもの のほかに，個人そのものを表現する目的をもって，そ の個人の行い得る可能な反応を含めた状態空間, ense mble，を想定する問題があり [9]，そこにエルゴード仮 説に類する原理を導入さぜるを得ない場合があると筆者 は考えているが，その点については機会を改めて述べる ことにしたい．

\section{交献}

1. Boring, E.G. (1933) The physical dimensions of consciousness. The Century Co. New York.

2. Boring, E.G. (1942) Sensation and perception in the history of experimental psychology. Appleton-Century-Crofts.

3. Boring, E.G. (1950) A history of experimental psychology. Appleton-Century-Crofts.

4. Carr, H.A. (1935) An introduction to space perception. Longmans, Green And Co.

5. Cherry, C. (1961) Two ears-but one world. In Rosendlith, W.A. (Ed.) Sensory communication, John Woley.

6. Hardy, L.H., Rand, G. \& Rittler, M.C. (1949) Investigation of visual space. Arch. of ophthal., 42, 53-63.

7. Hardy, L.H., et al., (1953) The geometry of binocular space perception. Knapp Memorial Laboratories Institute of Ophthalmology, Columbia University, College of Physicians and Surgeons.

8. 印宩太郎（1951） アイソモルフィスムの一問題 一知覚された点の位置について一哲学 27 輯 205 241.

9. 印東太郎（1959）心理測定, 応月社会心理学講座 第一卷. 基枅技術. 光文社 $12 \sim 45$.

10. Indow, T., Uchizono, T. (1960) Multidimensional mapping of Munsell colors varying in hue and chroma. J. Exp. Psychol., 59, 321-329.
11. Indow, T., Kanazawa, K. (1960) Multidimensional mapping of Munsell colors varying in hue, chroma, and value. J. Exp. Isychol., 59, 330-336.

12. 印東太郎（1960） マンセル表色系に含まれる心 理学的問題 (色彩スケール铬 2) 横川松三䬦先生古 稀部念心理学論文集.

13. Indow, T. et. al., (1962) An experimental study of the Luneburg theory of binocular space perception. (1) The 3-and 4-point experiments. Jap. Psychol. Res., 4, 6-16.

14. Indow, T. et. al., (1962) An Experimental study of the Luneburg theory of binocular space perception. (2) The alley experiments. Jap. Psychol. Res., 4, 7-24.

15. 印東太郎（1962） 因子分析㸺現代統忛学大辞 典，東洋経済新報社： $583-588$.

16. 石井克己 (1961) 諸恒常現象間の相阙に関する 研究 (第.1 報告) 一知喾恒常恻と Luneburg の視空 間理論一哲学年報 $23,39 \sim 57$.

17. Judd, D.B. (1935) Maxwell triangle yielding uniform chromaticity scales. J. Opt. Soc. Amer., 25, 24.

18. Lewin, K. (1935) A dynamic theory of personality, Selected papers, McGraw-Hill.

19. Lewin, K. (1939) Principles of topological psychology, McGraw-Hill.

20. Lawin, K. (1938) The conceptual representation and the measurement of psychological forces, Duke University Press.

21. Luneburg, R.K. (1947) Mathematical annlysis of binocular vision. Princeton University. Press.

22. Luneburg, R.K. (1948) Metric methods in binocular visual perception. Studies and Essays. Courant Anniversary Volume, 215-240.

23. Luneburg, R.K. (1950) The metric of binocular visual space. 40, 627-642.

24. MacAdam, D.L. (1943) Specification of small chromaticity differences. 33, 18-26.

25. Messick, S.J. (1956) The perception of social attitudes. J. Soc. Abn. Psychol., 52, 57-66.

26. Morton, A.S. (1959) Similarity as a determinant of friendship: A multidimensional study. $P h$. D. Thesis, Princeton University.

27. Ogle, K.N., et al., (1932) Corresponding retinal points, The Horopter and size and shape of ocular images. Part 1. 22, 538-574.

28. Ogle, K.N., et al., (1932) Corresponding retinal points, The Horopter and size and shape of ocular images. Part 2, 22, 575-631.

29. Ogle, K.N. (1932) Analytical treatment of the longitudinal horopter: Its measurement and application to related phenomena, especially to relative size and shape of ocular images. 22, 665-728. 
30. Ogle, K.N. (1938) Die Mathematische Analyse des Lan'shhoropters. Arch. f.d. Ges. Physiol., 239, 748-766.

31. Ogle, K. N. (1950) Researches in binocular vision. W.B. Saunders Co.

32. Shepard, R.N. (1962) The analysis of proximities: Multidimensional scaling with an unknown distance function I. Psychometrika, 27, 125-140. II. Ibid., 219-246.

33. 出彩科学協会編 (1962) 色彩科学ハンドブック 南江堂.

34. Silberstein, L. (1943) Investigations on the intrinsic peoperties of the color domein. II. 33, 1-10.

35. Torge rson, W.S. (1958) Theory and methods of scaling. John Wiley.

36. 戸田正直 (1951) 行動基礎理論の数理的研究. 心理的研究. 21, No. 2, 38-48.

37. von Békésy (1959) Similarities between hearing and skin sensations. Psychol. Rev. 66, 1-22.

38. von Senden, M. (1960) Space and sight. The Free Press.

39. Zajaczkowska, A. (1956) Experimental determination of Luneburg's $\sigma$ constnants and K. Quart. J. Exp. Psychol. 8, 66-78.

40. Zajaczowska, A. (1956) Experimental test of Luneburg's theory. Horopter and alley experiments. 46, 514-527.

\section{生命現象からみた決定論と自由}

\section{木 村 陽 二 郎}

「万物は流転する.」一刻も静止していない自然は先刻 の自然と現在の自然とは異ったものであり，ただ先刻の 自然と現在の自然とがつながっているというので同じ自 然というに過ぎない.

ラプラスのデーモンのように自然のすべてを知ったと しても何になろろか。 それは自然の変貌の流れをみるに 過ぎない：二度と同じ自然はあり得ないのだから，すべ てを知っているということは知らないことと同じような ものと思われる.

自然のすべての原因，数限りない原因結果の系列をさ かのぼり，遂には第一原因とか神とかいうべきものにた どりつくであろうか. そのような事はもちろん，人間わ ざでできることではない.

我々の知りたいのは同じ原因から同じ結果が生じると いうくりかえしである.このコスモスの花は美しい. そ こでその種子をもらって地にまく．来年もこの花を見た いからだ.このコスモスと来年のコスモスとは違うもの であっても，それで何の不都合があるだろう。コスモス であればそれで良い。

必要なのはコスモスの花の嘫いた後にできた種子だか ら，それをまけば来年もコスモスの花を咲かせるだろう という知軸である. 昨年のコスモス, 今年のコスモス, 来年のコスモス，みな違うだろらが，コスモスというこ とでは同じである.
科学の実験でたしかめる同一原因で同一結果を生じる ということもこれと同じに考えられる.同じ種子からは 同じ花が咲くに相違ない. 昨年の大学の庭のコスモスと 今年の私の庭のコスモスと違ったとしても，コスモスの イデアは変わらない. 自然の法則もイデアとして存在す る.ここでいうイデアはプラトンのイデアとは異るだろ う.ここでイデアの不変というのも, プラトンのイデア のように永久不滅のイデアではなく，その時において不 変というに過ぎない，人間が変わればイデアも変わり， 時がたてばコスモスもコスモスモドキという植物に変異 するかも知れない，あるいは，イデアそのものは変わら ないが，それは歴史の一時期におけるイデアとなり，い わば化石のイデアとなる.

同一原因，同一結果を生命現象についてみる. 生物は 無生物とは異るものを持つといわれた，無生物に問いか けた場合，同一条件下では定まった刺㦸や定まった操作 は定まった反応や定まった㗢きをもたらす。しかし，あ る定まった刺㦸に対して生物は定まった反応をもってむ くいないように思われた。無生物は自然法則に従い因果 律で理解できるが生物は無生物とは異り違った力, 自主 性をもつとされた.

これが 18 世紀のバルテ Bartez の生命原理 principle vital であり，ビシャ Bichat の生命力 force vitale で あり，20 世紀のドリーシュ Driesch のエンテレヒー 